FITRAH Jurnal Kajian Ilmu-ilmu Keislaman

Vol. 04 No. 2 Desember 2018

e-ISSN : 2460-2345, p-ISSN: 2442-6997

Web: jurnal.iain-padangsidimpuan.ac.id/index.php/F

\title{
STUDI ALQUR'AN TENTANG PERJANJIAN PERDAGANGAN LINTAS BATAS PEMERINTAH INDONESIA-MALAYSIA
}

\author{
MUZALIFAH \\ Fakultas Ekonomi dan Bisnis Islam IAIN Palangka Raya \\ Jalan G. Obos XII, Komplek Islamic Centre Palangka Raya. 73112 \\ kmuzalifah@ymail.com
}

\begin{abstract}
Cross-border trade agreement between Indonesia-Malaysia Government discuss about trading for the people residing in state borders area. However along with the times these agreements become less effectively. The mentioned because the agreement was long time ago and abuse of rigts by certain peoples. Thereby, the agreement needs reexamination because it is less relevant to the Indonesia economic development nowadays. It can also be detrimental to one of the parties in the state borders area. It is not contary to the tenetof islam as concept of fiqh rules on the basis of the society benefits that is part of a study of Al-Qur'an.
\end{abstract}

Keywords: Study of Al-Qur'an, Trade agreement

\begin{abstract}
Abstrak
Perjanjian perdagangan lintas batas antara Republik Indonesia dan Malaysia membahas tentang perdagangan untuk masyarakat yang berada di daerah perbatasan. Akan tetapi seiring dengan perkembangan zaman perjanjian tersebut menjadi kurang efektif. Hal tersebut dikarenakan usia perjanjian tersebut yang sudah tua dan penyalahgunaan hak oleh oknum tertentu. Dengan demikian, perjanjian tersebut perlu pengkajian ulang/revisi karena kurang relevan dengan perkembangan perekonomian Indonesia untuk saat ini dan dapat merugikan salah satu pihak yang berada di daerah perbatasan. Tindakan tersebut tidak bertentangan dengan ajaran Islam sebagaimana konsep kaidah fiqh atas dasar kemaslahatan yang merupakan bagian dari studi Alquran.
\end{abstract}

Kata kunci: studi Alquran, perjanjian perdagangan.

\section{PENDAHULUAN}

Perjanjian perdagangan lintas batas merupakan perjanjian atau kesepakatan yang dibuat oleh pemerintah Indonesia dan Malaysia untuk mengatur perdagangan lintas batas di daerah perbatasan, yang dalam tulisan ini peneliti singkat dengan ABT (Agreement on Border Trade). Perjanjian ini dibuat sebagai bentuk administratif dan intervensi oleh pemerintah Indonesia dan Malaysia untuk mengatur perdagangan lintas batas di daerah perbatasan Negara tersebut. Dengan demikian perjanjian( ABT) merupakan dasar hukum bagi 
FITRAH Jurnal Kajian Ilmu-ilmu Keislaman

Vol. 04 No. 2 Desember 2018

kedua Negara tersebut untuk melakukan perdagangan lintas batas. Berdasarkan paparan tersebut, maka yang terkena dampak dari perjanjian ini adalah masyarakat yang berada di daerah perbatasan. Masyarakat perbatasan dapat melakukan perdagangan lintas batas dengan catatan tidak melanggar kesepakan/perjanjian yang telah disepakati oleh kedua belah pihak.

Meskipun masyarakat perbatasan dapat dengan mudah keluar masuk pangkalan dalam dan luar negeri dalam hal perdagangan berdasarkan perjanjian tersebut tetapi bukan berarti masyarakat tersebut paham akan batas administrasi perdagangan, apalagi yang berhubungan dengan hukum maupun regulasi. Hal ini disebabkan oleh rendahnya tingkat pendidikan dan taraf perekonomian masyarakat di daerah tersebut, sedangkan untuk mengerakkan roda pembangunan dan ekonomi diperbatasan diperlukan SDM yang berkualitas. Tingkat pendidikan yang rendah menyebabkan minimnya akses kelapangan kerja maupun lapangan usaha. Oleh karena itu, tingkat pendidikan yang baik serta lapangan pekerjaan yang memadai didalam negeri perlu diwujudkan karena hal-hal ini terkait dengan martabat dan harga diri bangsa. ${ }^{1}$

Ketidaktahuan masyarakat perbatasan tentang regulasi dan administratif, memberikan celah bagi sekelompok orang untuk memanpaafkan situasi tersebut menjadi sebuah bisnis yang menjanjikan. Misal, ada sekelompok orang yang membeli barang ke luar negeri dengan memanfaatkan identitas masyarakat lintas batas tersebut. Sebagimana isi dalam perjanjian lintas batas, masyarakat hanya boleh berbelanja maksimal RM 600,-/bulan, akan tetapi dengan memanfaatkan identitas masyarakat para oknum tertentu bisa berbelanja hingga mencapai RM. 12.000,-/bulan. Dengan demikian, masyarakat tidak hanya rugi dari sisi hukum tetapi juga dari sisi finansial. ${ }^{2}$

Adapun isi perjanjian yang mengatur standar transaksi tersebut sebagaimana yang tercantum pada halaman 4 Agreement on Border Trade

1 Sutaryo dkk., Membangun Kedaulatan Bangsa Berdasarkan Nilai-nilai Pancasila: Pemberdayaan Masyarakat Dalam Kawasan Terluar, Terdepan, dan Tertinggal (3T): Kumpulan makalah call for papers kongres Pancasila VII (Yogyakarta: Pusat Studi Pancasila UGM, 2015), hlm. 323.

2 Edi Petebang, "Kisah Perbatasan:"Merah Putih di Dadaku; Malaysia di Perutku..." (Dimuat di Majalah KR edisi 169, September 2009)," diakses 19 Oktober 2016, https://www.facebook.com/notes/suara-rakyat/kisah-perbatasanmerah-putih-di-dadaku-malaysiadi-perutku/10150253228975487/?_rdc=1\&_rdr. 
Between the Government of the Republic of Indonesia and the Government of Malaysia sebagaiman tercantum pada foto di bawah ini: ${ }^{3}$

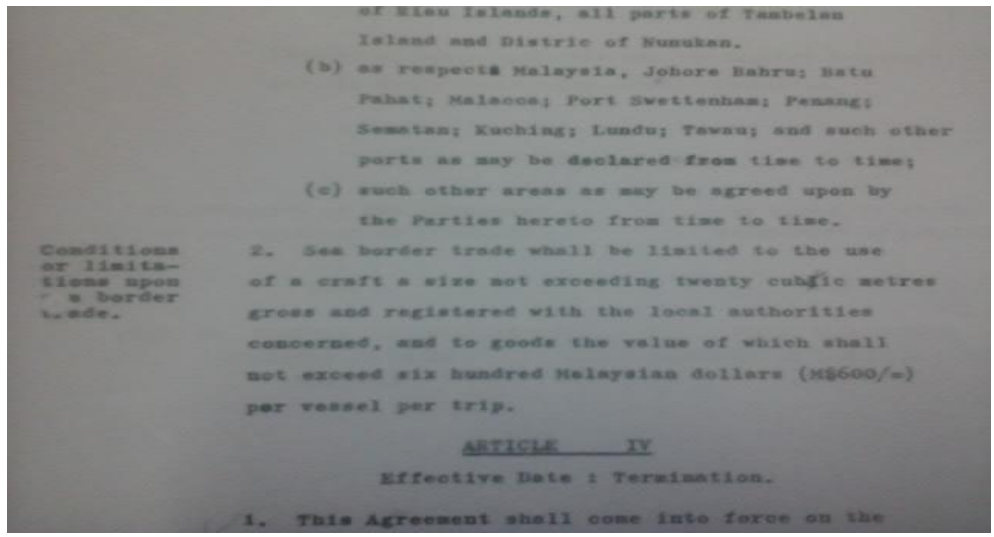

Selain di bidang ekonomi, pendidikan di daerah perbatasan juga sangat memprihatinkan. Banyak masyarakat yang putus sekolah. Hal tersebut dikarena terbatasnya akses dan fasilitas dari pemerintah dalam mengembangkan sarana dan prasarana pendidikan. Selain itu, tidak banyak guru-guru yang bersedia ditempatkan di lokasi tersebut. Hal ini disebabkan oleh beberapa faktor diantaranya adalah fasiltas dan sarana transportasi yang kurang memadai. Padahal pemerintah telah membuat kebijakan untuk memberikan insentif bagi guru-guru yang bersedia mengajar didaerah tersebut. Sepertinya nilai-nilai nasionalis dan pahlawan tanpa tanda jasa masih belum berperan degan maksimal di hati pejuang tersebut. ${ }^{4}$

Rendahnya pendidikan membuat masyarakat perbatasan bekerja dan berdagang hanya untuk memenuhi kebutuhan sehari-harinya, belum berpikir bahwa mereka adalah garis depan bagi Indonesia di mata dunia. Jika diumpamakan negara adalah sebuah rumah, maka daerah perbatasan adalah serambinya dimana kemolekannya dapat membangun citra bangsa. Dengan demikian nilai-nilai negara dan harga diri bangsa dipertaruhkan dalam hal ini. Oleh Karen itu, perlu perhatian khusus oleh pemerintah khususnya dalam membuat regulasi dan pengawasannya. Sebuah kebijakan yang dapat merubah nasib anak bangsa di tapal batas. Meskipun jiwa patriotisme masih ada dalam hati mereka, akan tetapi jika tidak dipupuk dengan pelukan hangat dari

${ }^{3}$ Agreement on Border Trade Between the Government of the Republic of Indonesiaa and the Government of Malaysia, hlm. 4

${ }^{4}$ Mustafa Abubakar, Menata Pulau-Pulau Kecil Perbatasan: Balajar dari Kasus Sempadan, Ligitan dan Sebatik, 2006 ed. (Jakarta: Kompas, t.t.), hlm. IX. 
FITRAH Jurnal Kajian Ilmu-ilmu Keislaman

Vol. 04 No. 2 Desember 2018

pemerintah maka bukan mustahil mereka akan berpaling dari Negara Indonesia. Pelukan hangat tersebut dapat berupa upaya peningkatan sumber daya manusia melalui pendidikan dan imprastruktur yang memadai.

Hubungan antara pendidikan dan perekonomian sangat signifikan karena dalam jangka panjang perekonomian akan ditentukan oleh kualitas human capital. Sejumlah penelitian menunjukkan bahwa human capital merupakan penentu prestasi perekonomian suatu Negara dalam jangka panjang. Eratnya hubungan antara pendidikan dan daya saing perkonomian menuntut lembaga pendidikan untuk memperbaiki diri agar dapat proaktif, modern dan fleksibel. Investasi terpenting bagi suatu perekonomian adalah pendidikan. ${ }^{5}$ Selain itu, Hubungan pendidikan dan produktivitas kerja dapat tercermin dalam tingkat penghasilan. Pendidikan yang lebih tinggi mengakibatkan produktivitas kerja yang lebih tinggi dan memungkinkan penghasilan yang lebih tinggi pula. Oleh karena itu investasi sumber daya manusia dalam pendidikan merupakan faktor yang penting, karena melalui perndidikan dapat melahirkan sumber daya manusia yang berkualitas sehingga dapat ikut berkontribusi dalam perekonomian dan pembangunan. ${ }^{6}$

Sebagaimana yang dilakukan oleh Negara Jepang, dimana kekuatan Jepang dewasa ini (dan akan datang) terletak pada tingginya tingkat investasi, dan baiknya tingkat pendidikan penduduknya. Tapi itu semua tidak menjadi berarti kalah dibandingkan kelemahannya. Pertama, pondasi pembangunan ekonomi Jepang masih bertumpu pada masa perang dunia. Jepang hati-hati dan lebih mengandalkan pasaran ekspor. Ini akan menjadi titik terlemah serangan lawan. Kedua Jepang lemah dalam inovasi produk baru, tetapi unggul di bidang teknologi proses. ${ }^{7}$ Lihat hasilnya sekarang! Negara Jepang sudah menjadi Negara maju yang diperhitungkan di mata dunia. Lalu bagaimana dengan Indonesia? Indonesia perlu motivator yang mampu merubah persepsi masyarakat, dan yang paling berpengaruh dalam hal ini adalah pemerintah. Ideologi Negara yaitu Pancasila merupakan sumber dari segala sumber hukum yang ada di Indonesia.

\footnotetext{
hlm. 47.

${ }^{6}$ Dr. H. Amiruddin Idris, S.E., M.Si, Pengantar ekonomi sumber daya manusia (Yogyakarta: Deepublish (Grup penerbitan CV budi utama), 2016), hlm. 31.

${ }^{7}$ New business model: strategi ampuh menangani bisnis abad ke-21 (bagaimana perusahaan lama bertahan dan perusahaan baru masuk) (Jakarta: PT alex Media Komputindo (kelompok GRAMEDIA), 2005), hlm. 45.
}

${ }^{5}$ Darmin Nasution, Bank sentral itu harus membumi (Yogyakarta: Galang Pustaka, 2013), 
Pancasila dasar negara dapat "diterapkan" dalam kehidupan ekonomi bangsa, negara dan masyarakat sebagai berikut: ${ }^{2}$

1. Ketuhanan yang Maha Esa. Roda perekonomian digerakkan oleh ransanganransangan ekonomi, sosial dan moral

2. Kemanusiaan yang adil dan beradab. Ada kehendak kuat dari seluruh masyarakat untuk mewujudkan kemerataan sosial (egalitarian), sesuai asasasas kemanusiaan

3. Persatuan Indonesia. Prioritas kebijaksanaan ekonomi adalah menciptakan perekonomian nasional yang tangguh. Ini berarti nasionalisme menjiwai setiap kebijaksanaan ekonomi.

4. Kerakyatan yang dipimpin oleh hikmat kebijaksanaan dalam permusyawaratan/perwakilan. Koperasi merupakan sokoguru perekonomian dan merupakan bentuk paling konkrit dari usaha bersama

5. Keadilan sosial bagi seluruh rakyat Indonesia. Adanya imbangan yang jelas dan tegas antara perencanaan ditingkat nasional dengan desentralisasi dan pelaksanaan kebijakan ekonomi untuk mencapai keadilan ekonomi dan keadilan sosial.

Paparan tersebut merupakan cikal bakal yang lahir dari nilai-nilai Pancasila dapat membuat sejarah peradaban bagi Indonesia. Melahirkan para cendikia dan mampu membawa masyarakat ketujuan yang sesungguhnya, sebagaimana yang tercantum pada alenia ke-empat Pembukaan UUD 1945, yaitu:

Kemudian daripada itu untuk membentuk suatu Pemerintah Negara Indonesia yang melindungi segenap bangsa Indonesia dan seluruh tumpah darah Indonesia dan untuk memajukan kesejahteraan umum,mencerdaskan kehidupan bangsa, dan ikut melaksanakan ketertiban dunia yang berdasarkan kemerdekaan, perdamaian abadi dan keadilan sosial, maka disusunlah kemerdekaan kebangsaan Indonesia itu dalam suatu Undang-Undang Dasar Negara Indonesia, yang terbentuk dalam suatu susunan Negara Republik Indonesia yangberkedaulatan rakyat dengan berdasar kepada Ketuhan Yang Maha Esa, Kemanusiaan yang adil dan berasab, Persatuan Indonesia, dan Kerakyatan yang dipimpin oleh hikmat kebijaksanaan dalam permusyawaratan/perwa-

8 Oetojo Oesman, Alfian, dan Indonesia Badan Pembinaan Pendidikan Pelaksanaan Pedoman Penghayatan dan Pengamalan Pancasila, Pancasila sebagai ideologi dalam berbagai bidang kehidupan bermasyarakat, berbangsa, dan bernegara (Jakarta: BP-7 Pusat, 1991), hlm. 240-241. 
FITRAH Jurnal Kajian Ilmu-ilmu Keislaman

Vol. 04 No. 2 Desember 2018

kilan, serta dengan mewujudkan suatu keadilan srosial bagi seluruh rakyat Indonesia. ${ }^{9}$

Nilai-nilai agama yang tercantum dalam sila ke-satu Pancasila, yang secara tidak langsung mengajarkan kepada masyarakatnya tentang ajaran tauhid, saling menghormati dan toleransi terhadap umat beragama. Dengan demikian dapat dikatakan bahwa Indonesia mengakui agama, meskipun Indonesia bukan negara agama. ${ }^{10}$ Merasa memiliki menjadi akan sesuatu hal lah yang mampu merubah segalanya bahkan sebuah sistem. Akan tetapi dengan menggali potensi masyarakat Indonesia, khususnya pemerintah untuk manjadi pelopor untuk menciptakan sebuah perubahan bagi masyarakat perbatasan. Bukan tidak mungkin pemerintah bisa menjadikan daerah perbatasan sebagai destisasi bagi masyarakat internasional dengan mencari sumber yang potensial dari masyarakat perbatasan, yaitu dengan memunculkan karya anak bangsa di tapal batas sebagai hak cipta Indonesia. Dengan demikian, tingkat perekonomian masyarakat dapat ditingkatkan dan pertayaan terbesar adalah upaya apa yang akan dilakukan pemerintah dalam hal ini?

Berdasarkan paparan tersebut di atas menyatakan pentingnya peran serta pemerintah untuk memperhatikan tingkat pendidikan dan perekonomian daerah perbatasan sebagai upaya untuk meningkatkan kesejahteraan masyarakat perbatasan khsususnya. Oleh karena itu, salah satu langkah kongkrit yang bisa membuka mata pemerintah untuk memperhatikan daerah perbatasan adalah dengan membuat sebuah penelitian yang tidak hanya membahas dari sisi materil tetapi juga dari sisi spritualnya. Maka dari itu, penulis sangat tertarik menulis dengan judul "Studi Alqur'an tentang Perjanjian Perdagangan Lintas Batas Pemerintah Indonesia-Malaysia".

Berdasarkan latar belakang masalah di atas, maka yang menjadi masalah dalam penelitian ini adalah bagaimana Studi Alqur'an tentang Perjanjian Perdagangan Lintas Batas Pemerintah Indonesia-Malaysia? Dengan sub masalah sebagai berikut:

1. Bagaimana efektivitas Agreement on Border Trade Between the Government of the Republic of Indonesia and the Government of Malaysia terhadap mekanisme pasar diperbatasan?

${ }_{9}^{9}$ DPR Republik Indonesia, UUD 1945 (Jakarta: Visi Media, 2007), Alenia ke-empat.

${ }^{10}$ Kementrian Agama RI, Penistaan Agama dalam Persfektif Pemuka Agama Islam (Jakarta: Puslitbang Kehidupan Keagamaan Badan Litbang dan Diklat Puslitbang Kementrian Agama RI, 2014), hlm. 243. 
2. Bagaimana sudut pandang Alqur'an terhadap Agreement on Border Trade Between the Government of the Republic of Indonesia and the Government of Malaysia?

\section{METODE PENELITIAN}

Penelitian ini menggunakan metode kualitatif dengan pendekatan normatif. Sumber data primer dalam penelitian ini adalah perjanjian perdagangan lintas batas antara Indonesia dan Malaysia, sedangkan data sekunder adalah peraturan dan perundang-undangan yang mendukung teori tentang perjanjian perdagangan lintas batas tersebut yang dipublikasikan di media cetak maupun media sosial. Dengan demikian teknik pengumpulan data dalam penelitian ini menggunakan library riset atau telaah pustaka. Sedangkan untuk menganalisis data dalam hal ini adalah dengan cara mengkolaborasikan antara hukum positif (regulasi) pemerintah dalam bentuk perjanjian perdagangan lintas batas dengan sumber hukum Islam yang relevan dengannya, kemudian baru ditarik kesimpulan atas konsep maslahah.

\section{HASIL PENELITIAN DAN PEMBAHASAN}

Efektivitas Agreement on Border Trade between the Government of the Republic of Indonesia and the Government of Malaysia terhadap mekanisme pasar diperbatasan

Peraturan yang buat oleh pemerintah dan disahkan oleh DPR otomatis menjadi hukum tertulis yang harus dipatuhi dan mengikat setiap warga Negara. Dalam hal ini fingsi DPR adalah lembaga legislasi yang menjalankan kekuasaannya membentuk Undang-undang ${ }^{11}$. Demikian halnya hukum atau peraturan tentang lintas batas negara. Peraturan tersebut akan mengikat para pihak yang telah membuat kesepakatan dalam bentuk perjanjian bilateral misalnya yaitu antara Malaysia dan Indonesia di lintas batas Entikong. Perjanjian yang telah disepakati menjadi hukum bagi para pihak yang membuat kesepakatan. Meskipun demikian pada umumnya, perjanjian tidak terikat sepada suatu bentuk tertentu, dapat dibuat secara lisan, dan andaikata dibuat tertulis maka perjanjian bersifat sebagai alat pembuktian apabila terjadi perselisihan ${ }^{12}$.

11 A.M. Fatwa, Potret konstitusi Pasca amandemen UUD 1945 (Jakarta: PT Kompas Media Nusantara, 2009), hlm. 116.

${ }^{12}$ Richard Eddy, Aspek legal property: teori, contoh dan aplikasi (Yogyakarta: CV. Andi Offset (ANDI), 2010), hlm. 45. 
FITRAH Jurnal Kajian Ilmu-ilmu Keislaman

Vol. 04 No. 2 Desember 2018

Perjanjian bilateral atau biasa juga disebut traktat adalah perjanjian antara dua Negara ${ }^{13}$, yang dalam hal ini adalah perjanjian antara Negara Indonesia dan Malaysia dalam bentuk perjanjian perdagangan lintas batas antara kedua Negara tersebut. Perjanjian bilateral sebagaimana yang dimaksud paling sedikit memuat: (a) tempat pemasukan atau pengeluaran lintas batas yang ditetapkan; (b) jenis barang yang diperdagangkan; (c) nilai maksimal transaksi pembelian barang di luar daerah pabean untuk dibawa ke dalam daerah pabean; (d) wilayah tertentu yang dapat dilakukan perdagangan perbatasan; dan (e) kepemilikan identitas orang yang melakukan perdagangan perbatasan. ${ }^{14}$

Dalam bidang ekonomi perjanjian sering disebut dengan kontrak, selain bidang tersebut perjanjian disebut dengan agreement. Pemisahan kata tersebut diterapkan di Amerika, sedangkan di Indonesia, perjanjian itu sama dengan akad menurut hukum Islam, meskipun demikian substansinya sama, tidak ada perbedaan antara penjanjian dibidang ekonomi dan yang lainnya karena keduaduanya harus memenuhi syarat sahnya suatu perjanjian, jika tidak maka perjanjian tersebut batal/dapat dibatalkan. Adapun syarat sahnya perjanjian berdasarkan pasal $1230 \mathrm{KUH}$ Perdata antara lain sebagai berikut: (1) Mereka sepakat untuk mengikatkan diri; (2) Cakap untuk membuat suatu perikatan; (3) Suatu hak tertentu; dan (4) Suatu sebab yang halal ${ }^{15}$.

Perjanjian perdagangan lintas batas antara Indonesia dan Malaysia dibuat dan disahkan pada masa pemerintahan Suharto yaitu pada tahun 1970. Perjanjian inilah yang menjadi cikal bakal sistem perdagangan yang terjadi di perbatasan Indonesia-Malaysia khususnya. Akan tetapi seiring berkembangnya zaman perjanjian sudah kurang maksimal menjadi landasan hukum perdagangan lintas batas di dua negara tersebut. Oleh karena itu perlu adanya revisi oleh para pihak yang telah membuat kesepakatan atau perjanjian tersebut, yaitu antara pemerintahan Indonesia dan Malaysia. Selain itu, sudah lebih dari 37 tahun perjanjian tersebut dilaksanakan akan tetapi belum ada langkah riil untuk melakukan perubahan. Misanya dalam hal-hal yang berhubungan dengan dengan sanksi-sanksi atas pelanggaran yang dibuat karena mengingat perjanjian

${ }^{13}$ Disiblin hukum yang mewujudkan kesetaraan dan keadilan gender (Jakarta: Yayasan Pustaka Obor Indonesia, 2012), hlm. 89.

14 Kementerian Perdagangan RI, "Menggenggam Stabilitas Harga Pangan," Publikasi Internal Kementrian Perdagangan Republik Indonesia, INTRA Indonesia TradeInsight 2015, no. V (2014): $1-73$.

${ }^{15}$ Eddy, Aspek legal property: teori,. ., hlm. 45. 
ini sifatnya sangat penting yaitu mengenai harga diri setiap negara yang bersangkutan.

Perdagangan perbatasan juga mendapat perhatian dalam UU Perdagangan. Pada Pasal 55 disebutkan bahwa setiap warga negara Indonesia yang bertempat tinggal di wilayah Negara Kesatuan Republik Indonesia yang berbatasan langsung dengan negara lain dapat melakukan perdagangan perbatasan dengan penduduk negara lain yang bertempat tinggal di wilayah perbatasan. Namun perdagangan perbatasan tersebut hanya dapat dilakukan di wilayah perbatasan darat dan perbatasan laut yang ditetapkan dalam Peraturan Pemerintah, dan dilakukan berdasarkan perjanjian bilateral sesuai dengan ketentuan peraturan perundang-undangan. ${ }^{16}$

Kesepakatan dalam bentuk perjanjian perdagangan lintas batas antara pemerintah Indonesia dan Malaysia tersebut perlu diimplementasikan dengan sebaik-baiknya dan jika diperlukan maka pemerintah bisa melakukan intervensi dalam bentuk kebijakan tulisan maupun himbauan kepada warga Negara yang berada dan tinggal di daerah perbatasan. Tindakan tersebut sejalan dengan pernyataan Dwijowijoto bahwa implementasi mengacu pada tindakan untuk mencapai tujuan-tujuan yang telah ditetapkan dalam suatu keputusan, tindakan ini berusaha untuk mengubah keputusan-keputusan tersebut menjadi pola-pola operasional serta berusaha mencapai perubahan-perubahan besar atau kecil sebagaimana yang telah diputuskan sebelumnya. Dalam artian bahwa implementasi kebijakan pada prinsipnya adalah cara agar sebuah kebijakan dapat mencapai tujuan. ${ }^{17}$

Implementasi pada hakikatnya juga upaya pemahaman apa yang seharusnya terjadi setelah sebuah program dilaksanakan. Atau dengan kata lain, bahwa tujuan kebijakan adalah melakukan intervensi. Oleh karen itu, implementasi kebijakan sebenarnya adalah tindakan intervensi itu sendiri. Mazmanian dan Sabatier dalam Dwijowijoto memberikan gambaran bagaimana melakukan intervensi atau implementasi kebijakan dalam langkah berurutan berikut: ${ }^{18}$

\footnotetext{
${ }^{16}$ Kementerian Perdagangan RI, “Menggenggam Stabilitas Harga Pangan.”

${ }^{17}$ Shofari Sstp Abdul Kadir, "Implementasi Kebijakan Pengelolaan Pasar Tradisional Di

Kabupaten Bantul” (Tesis, Universitas Gadjah Mada, 2011), hlm. 15, http://etd.repository.ugm.ac.id/index.php?mod=penelitian_detail\&sub=PenelitianDetail\&act=view \&typ=html\&buku_id=50535\&obyek_id=4.

${ }^{18}$ Abdul Kadir, “Implementasi Kebijakan Pengelolaan Pasar....,” hlm. 15-16.
} 
FITRAH Jurnal Kajian Ilmu-ilmu Keislaman

Vol. 04 No. 2 Desember 2018

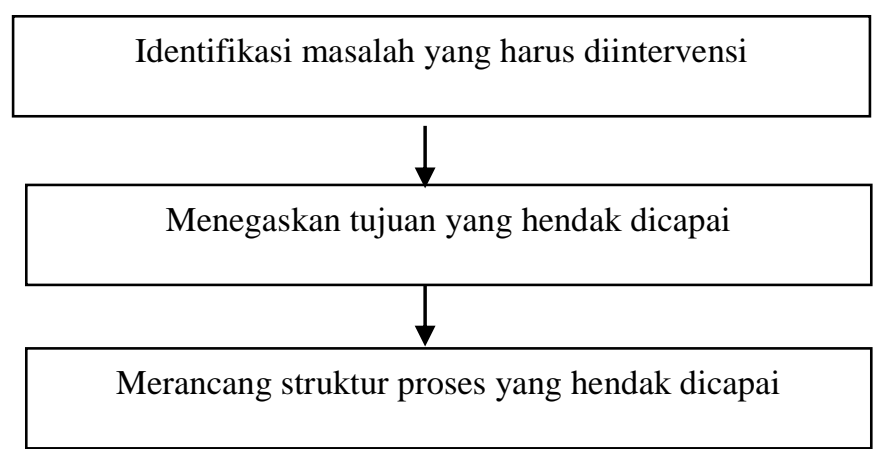

Berdasarkan pada pernyataan Dwijowijoto tersebut, maka perjanjian perdagangan tersebut seyogianya sudah terimplemetasi dengan baik dan berjalan sebagaimana yang diharapkan oleh pemerintah Indonesia dan Malaysia. Meskipun demikian ada beberapa hal yang perlu mendapatkan perhatian khusus oleh kedua Negara tersebut, khsusnya dalam hal mekanisme perdagangan sebagaimana yang dicantumkan dalam perjanjian tersebut. Diantaranya adalah penyalahgunaan hak oleh oknum tertentu untuk melakukan transaksi perdagangan lintas batas sebagaimana yang diatur dalam perjanjian tersebut. Bentuk pelanggaran tersebut diantaranya adalah berbelanja melebihi RM. 600,- /bulan dengan memanfaatkan identitas penduduk setempat. Sanksi untuk tindakan tersebut belum dicantumkan pada perjanjian bilateral tersebut. Hal memperlihatkan bahwa perjanjian perdagangan tersebut sudah kurang relevan dengan perkembangan perekonomian kedua Negara, yaitu antara Negara Indonesia dan Malaysia.

Berdasarkan paparan di atas, maka efektivitas perjanjian tersebut sudah mulai berkurang karena dapat merugikan salah satu pihak yang berdampak pada perubahan sistem perekonomian yang ada diperbatasan. Oleh Karen itu, nilai-nilai hukum hendaknya ditamankan sejak dini kepada masyarakat, mengingat masyarakat selaku warga Negara memiliki hak dan kewajiban yang sama dimata hukum yang perlu dilindungi oleh pemerintah, sebagaimana regulasi pemerintah tentang persamaan hak diantaranya ada pada peraturan dan perundang-undangan berikut ini:

1. Tiap-tiap warga Negara berhak atas pekerjaan dan penghidupan yang layak bagi kemanusiaan. ${ }^{19}$

2. Setiap orang berhak atas pemenuhan kebutuhan dasarnya untuk tumbuh dan berkembang secara layak. ${ }^{20}$

${ }^{19}$ DPR Republik Indonesia, UUD 1945, Pasal 27 ayat (2). 
3. Pasal 38 UU nomor 39/1999 mengenai Hak Asasi Manusia: (1) “ Setiap warga Negara, sesuai dengan bakat, kecakapan dan kemampuan, berhak atas pekerjaan yang layak dan (2) Setiap orang berhak dengan bebas memilih pekerjaan yang di sukainya dan ...",

4. Pasal 13 UU nomor 09/1995 tentang usaha kecil: "Pemerintah menumbuhkan iklim usaha dalam aspek perlindungan, dengan menetapkan peraturan perundang-undangan dan kebijaksanaan untuk : (1) menentukan peruntukan tempat usaha yang meliputi pemberian lokasi di pasar, ruang pertokoan, lokasi sentra industri, lokasi pertanian rakyat, lokasi pertambangan rakyat, dan lokasi yang wajar bagi pedagang kecil dan (2) memberikan bantuan konsultasi hukum dan pembelaan.

Secara tidak lansung peraturan dan perundang-undangan tersebut di atas telah mengikat para pihak agar patuh dan taat pada peraturan dan perundangundangan yang telah dibuat oleh pemerintah Indonesia khususnya. Dengan demikian kepala negara wajib membela dan memberi perlindungan kepada rakyat serta menyelesaikan segala rupa kemaslahan mereka, baik mengenai dunia mapun akhirat. ${ }^{21}$

\section{Sudut Pandang Alqur'an Terhadap Agreement on Border Trade Between the Government of the Republic of Indonesiaa and the Government of Malaysia.}

Keterlibatan pemerintah dalam pasar bukanlah hal yang bersifat sementara atau sesaat. Ekonomi Islam memandang pemerintah dalam pasar merupakan satu kesatuan (co-existing) dengan unit ekonomi lainnya dengan dasar yang permanen dan stabil. Dalam hal ini, pemerintah bertindak sebagai perencana, supervisor, produsen, juga sebagai konsumen. ${ }^{22}$ Selain itu, pada dasarnya peran pemerintah dalam perkonomian yang Islami, memiliki dasar rasionalitas yang kokoh. Peran pemerintah dalam Islam didasari oleh beberapa argumentasi, yaitu:23 (1) Derivasi dari konsep kekhalifahan; (2) Konsekuensi

${ }^{20}$ DPR RI, “UU No.39 Thn 1999 - Hak Asasi Manusia (HAM),” Web. Blog, UU No.39 Thn 1999 - Hak Asasi Manusia (HAM), 1999, Pasal 11, http://hukum.unsrat.ac.id/uu/uu_39_99.htm.

${ }^{21}$ Muhammad Hasbi Ash-Shiddieqy, Hukum-Hukum Figh Islam yang Berkembang dalam Kalangan Ahlus Sunnah, cet-5 (Jakarta: Bulan Bintang, 1978), hlm. 581.

${ }^{22}$ Ekonomi Mikro dalam Prespektif Islam (Yogyakarta: BPFE-Yogyakarta, 2004), hlm. 377-378.

${ }^{23}$ Pusat Pengkajian dan Pengembangan Ekonomi Islam (P3EI) Universitas Islam Indonesia atas kerja sama dengan Bank Indonesia, Ekonomi Islam (Jakarta: PT Raja Grafindo Persada, 2008), hlm. 446 . 
FITRAH Jurnal Kajian Ilmu-ilmu Keislaman

Vol. 04 No. 2 Desember 2018

adanya kewajiban-kewajiban kolektif (fard al-kifayah); (3) Adanya kegagalan pasar dalam merealisasikan falah.

Adapun peran pemerintah yang berkaitan dengan mekanisme pasar diantaranya meliputi:24 (1) Secara umum memastikan dan menjaga agar mekanisme pasar dapat bersaing dengan sempurna; (2) Membuat berbagai langkah untuk meningkatkan daya saing (conpetitiveness) dan daya beli (purchasing power) dari para pelaku pasar yang lemah, misalnya produsen kecil dan konsumen miskin; (3) Mengambil berbagai kebijakan untuk menciptakan harga yang adil, terutama seandainya persaingan yang sempurna tidak dimungkinkan terjadi pada pasar. Kegagalan pasar juga merupakan latar belakang perlunya pemerintah untuk berperan dalam perekonomian.

Pasar gagal dalam menyelesaikan beberapa permasalahan ekonomi karena dua hal, yaitu: (1) ketidaksempurnaan mekanisme kerja pasar; dan (2) tidak berjalannya mekanisme kerja pasar dengan efesien. ${ }^{25}$ Berdasarkan peran tersebut, maka pemerintah adalah pemegang amanah Allah untuk menjalankan tugas-tugas kolektif dalam mewujudkan kesejahteraan dan keadilan (al-adl wal ihsan) serta tata kehidupan yang baik (hayyah thayyibah) bagi seluruh umat. Pemerintah dapat memiliki peranan penting dalam menjalankan fard al-kifayah ini karena kemungkinan masyarakat gagal untuk menjalankan atau tidak dapat melaksanakannya dengan baik. Kemungkinan kegagalan masyarakat dalam menjalankan fard al-kifayah ini disebabkan beberapa hal, yaitu: ${ }^{26}$ (1) Asimetri dan kekurangan informasi; (2) Pelanggaran moral; (3) Kekurangan sumber daya atau kesulitan teknis.

Keterlibatan pemerintah dalam mewujudkan kesejahteraan masyarakat sebagaimana paparan di atas sangat penting, mengingat wilayah Indonesia yang sangat luas. Hal tersebut membutuhkan sebuah konsep yang dapat meningkatkan persatuan dan kesatuan bangsa Indonesia, diantaranya adalah dengan menanamkan nilai-nilai pancasila dan wawasan nusantara dalam jiwa bangsa Indonesia. Adapun yang dimaksud dengan wawasan nusantara adalah cara pandang bangsa Indonesia tentang diri dan lingkungannya berdasarkan

\footnotetext{
${ }^{24}$ Pusat Pengkajian dan Pengembangan Ekonomi Islam (P3EI) Universitas Islam Indonesia atas kerja sama dengan Bank Indonesia, hlm. 462.

${ }_{25}$ Pusat Pengkajian dan Pengembangan Ekonomi Islam (P3EI) Universitas Islam Indonesia atas kerja sama dengan Bank Indonesia, hlm. 448.

${ }^{26}$ Pusat Pengkajian dan Pengembangan Ekonomi Islam (P3EI) Universitas Islam Indonesia atas kerja sama dengan Bank Indonesia, hlm. 447.
} 
ideology nasional yang dilandasi oleh Pancasila dan UUD 1945 yang merupakan aspirasi bangsa Indonesia yang merdeka,berdaulat dan bermanfaat, serta menjiwai tata hidup dan tindak kebijakan dalam mencapai tujuan nasional. ${ }^{27}$

Wawasan nusantara yang dibingkai agama, bisa dijadikan pertimbangan untuk melakukan perubahan. Perubahan tersebut dapat berupa sebuah regulasi untuk meningkatkan taraf perekonomian masyarakat di tapal batas. Regulasi merupakan peraturan tertulis dalam bentuk perundang-undangan yang memuat hak, kewajiban dan sanksi bagi setiap warga negara. Adapun Kebijakan dan strategi implementasi wawasan nusantara meliputi tahap perumusan haluan negara, perencanaan jangka panjang, jangka sedang dan jangka pendek, pelaksanaan serta penilaian. ${ }^{28}$

Regulasi dalam bentuk peraturan dan perundang-undangan dibuat bukan untuk dilanggar, tetapi untuk ditaati dan dipatuhi karena produk hukum tersebut adalah bentuk abstrak yang merupakan perpanjangan tangan dari pemerintah untuk dilaksanakan oleh masyarakat/rakyat yang mengikatkan diri dengan NKRI. Meskipun demikian, hukum yang telah dibuat oleh manusia tidak akan bisa menandingi hukum Allah SWT dalam Alqur'an. Hal tersebut dikarenakan, firman Allah tersebut bersifat universal ${ }^{29}$ dan pleksibel. Pemahaman kontekstual akan firman Allah tersebut dengan pemikiranpemikiran manusia yang diilhami oleh Allah SWT dalam bentuk akal bisa dijabarkan dalam bentuk peraturan dan perundangan yang ada di Indonesia khususnya, selama tidak menyimpang dari nilai-ke-Islam-an. hal tersebut sejalan dengan teori konstektual yang dikemukakan oleh J. R Firth (1930) yang menegaskan makna sebuah kata yang senantiasa terikat pada lingkungan kultural dan ekologis pemakai bahasa tertentu. ${ }^{30}$

Dalam hal muamalah, dikatakan bahwa apapun boleh dilakukan selama tidak menyimpang dari ajaran Islam, karena secara umum, muamalah diartikan sebagai aturan-aturan (hukum-hukum) Allah untuk mengatur manusia dalam

${ }^{27}$ Aa Nurdiaman dan Betty Susilawati, Pendidikan Kewarganegaraan: Kecakapan Berbangsa dan Bernegara (Jakarta: PT. Pribumi Mekar, 2017).

${ }^{28}$ Santoso Soeroso, Mengarusutamakan pembangunan berwawasan kependudukan di Indonesia (Jakarta: Buku kedokteran EGC, 2005), hlm. 2.

${ }^{29}$ Fadlolan Musyaffa' Mu'thi, M.A, Islam Agama Mudah: Aplikasi Kaidah "al-Masaqqah Tajlib al-Tairis" dalam Konteks Keindonesiaan (Semarang: Syauqi Press, 2007), hlm. 7.

${ }^{30}$ Aam Abdillah dan dkk, Model Penelitian Agama dan Dinamika Sosial: Himpunan Rencana Penelitian (Jakarta: PT Raja grafindo Persada, 2002), hlm. 23-24. 
FITRAH Jurnal Kajian Ilmu-ilmu Keislaman

Vol. 04 No. 2 Desember 2018

kaitannya dengan urusan duniawi dalam pergaulan sosial. ${ }^{31}$ Jika ditinjau dari sisi perekonomian, hal tersebut dikarenakan perkembangan perekonomian yang terjadi saat ini berbeda dengan perekonomian yang terjadi pada zaman Rasulullah SAW. Selain itu, pada zaman dahulu kebijakan perdagangan masih bisa dikendalikan oleh kepemimpinan Beliau SAW ${ }^{32}$, akan tetapi setelah kepergian Beliau kebijakan mulai tidak menentu, hal tersebut dikarenakan beberapa hal diantaranya adalah masalah politik dan perebutan kekuasaan yang berujung pada terbunuhnnya sahabat Rasulullah, yaitu Ali bin Abu Tholib.

Hal di atas menjelaskan bahwa pentingnya peran pemimpin dalam sebuah negara. Peraturan dan perundang-undangan yang dibuat oleh pemerintah adalah titah yang harus dilaksanakan selama tidak bertentangan dengan syariah Islam. Karena pemimpin negara adalah khalifah yang merupakan perpanjangan tangan untuk menyebarkan siar Islam yang harus ditaati peraturannya. Sebagaimana firman Allah SWT yang artinya:

Hai orang-orang yang beriman, taatilah Allah dan taatilah Rasul-Nya, dan ulil amri di antara kamu. Kemudian jika kamu berlainan pendapat tentang sesuatu, maka kembalikanlah ia kepada Alqur'an da Rasul (sunnahnya), jika kamu benar-benar beriman kepada Allah dan hari kemudian. Yang demikian itu lebih utama (bagimu) dan lebih baik akibatnya. ${ }^{33}$

Firman Allah SWT di atas menjelaskan kepada umat untuk taat kepada pemimpinnya selama kebijakan tersebut tidak menyimpang dari ajaran Islam. Meskipun demikian, produk hukum yang dibuat tersebut adalah hasil pemikiran manusia yang yang levelnya tidak akan sama dengan wahyu Allah SWT yaitu Alqur'an yang sifatnya universal, pleksibel dan sesuai sepanjang masa. Oleh karena itu bukan hal yang baru jika terjadi perubahan-perubahan atas kebijakan yang telah dibuat karena perkembangan zaman yang diluar pemikiran manusia atas dasar maslahah.

Kemaslahatan masyarakat perbatasan dalam hal ini perlu perhatian khusus dalam bentuk materil maupun spiritual. Materil bisa dalam bentuk pembangunan infastruktur sedangkan spiritual dapat diimplemetasikan dalam bentuk pembangunan mental yang bisa dilakukan melalui pendidikan dan dakwah/siar Islam. Oleh karena itu kebijakan hendaknya berpijak pada

${ }^{31}$ Prof. Dr. H. Abdul Rahman Ghazaly, M.A dan dkk, Fiqh Muamalat (Jakarta: Kencana, 2012), hlm. 3.

${ }^{32}$ Mu'thi, M.A, Islam Agama Mudah: Aplikasi Kaidah “al-Masaqqah ..., hlm. 7.

${ }^{33}$ QS. An-Nisa' (4): 59 
kebutuhan sebagaimana Konsep al-Ghazali yang terdapat dalam kitabnya ushulu al-Khamsah dan prinsip fiqh Islam ( misal kaidah fiqh 'tasharraful imam 'ala ma ra'ya bil mashlahah "kepentingan umum" dalam menjalankan kebijakan dan programnnya) dalam mengenalkan prinsip demokrasi. ${ }^{34}$ Selain itu, kemaslahatan dapat diukur melalui beberapa hal diantaranya adalah yang sekemukakan tokoh Islam, yaitu: ${ }^{35}$

Menurut al-Buti, kemaslahatan dapat diukur melalui tiga hal:

1. Inheren pada maqasidusy-syariah

2. Tidak bertentangan dengan Alqur'an dan as-sunnah

3. Tidak bertentangan dengan akal sehat

Sementara menurut Ibnu Asyur, kamaslahatan dapat dilihat dari salah satu dari lima hal:

1. Bahwa maslahah dan mafsadah-nya bisa dibuktikan secara nyata

2. Bahwa maslahah dan mafsadah-nya secara jelas dapat dipahami oleh para ulama dan cendikiawan

3. Bahwa maslahah dan mafsadah-nya dapat diukur, apakah lebih besar maslahah atau mudarrah-nya. Tentu saja, upaya pembandingan tersebut harus dilakukan oleh meraka yang berkompeten.

4. Bahwa salah satu dari maslahah dan mafsadah- yang memiliki kadar yang sama atau seimbang- dapat dijelaskan dengan menampilkan sejenisnya yang lebih mengunggulkan salah satunya.

5. Bahwa salah satunya diukur dan nyata, sedangkan lainnya mengandung bahaya.

Yang pasti sebagai ukuran maqasidusy-syariah, seharusnya mengacu kepada kamaslahatan umum (al-maslahah al-ammah)

Berdasarkan paparan tersebut, dapat ditarik benang merah bahwa kebijakan pemerintah yang mementingkan mayoritas masyarakat perbatasan khususnya adalah tidak bertentangan dengan syariat Islam sebagaimana standar ukur kemaslahatan tersebut di atas. Dengan demikian, pada dasarnya membuat perjanjian itu dibolehkan dalam Islam selama perjanjian tersebut tidak mendatangkan kemudharatan para pihak dan sejalan dengan ajaran Islam.

34 Fuad Fachruddin, Agama dan Pendidikan Demokrasi: Pengalaman Muhammadiyah dan Nahdlatul Ulama (Jakarta: Pustaka Alvabet dan Yayasan INSEP, 2006), hlm. 219.

${ }^{35}$ Kementrian agama RI, Tafsir al-qur'an tematik: pembangunan ekonomi umat (Jakarta: PT. sinergi pustaka Indonesia, 2012). 
FITRAH Jurnal Kajian Ilmu-ilmu Keislaman

Vol. 04 No. 2 Desember 2018

Meskipun demikian, perjanjian merupakan hukum perdata yang erat hubungannya dengan muamalah. Selama kesepakatan tersebut tidak bertantangan dengan ajaran Islam, maka itu dibolehkan.

Selain hal tersebut di atas, konsep ekonomi Islam secara substansi sudah masuk dalam butir-butir perjanjian Agreement on Border Trade Between the Government of the Republic of Indonesia and the Government of Malaysia yang bertujuan untuk kemakmuran masyarakat perbatasan khususnya, meskipun demikian perjanjian tersebut juga perlu direvisi agar konsep kemaslahatannya terlihat jelas. Dengan demikian dengan konsep Ekonomi Islam dapat membantu merealisasikan kesejahteraan manusia melalui alokasi dan distribusi sumbersumber daya diperbatasan yang seirama dengan maqashid asy syariah. menurut as-Shatibi yaitu menjaga agama (li hifdz al din), jiwa manusia (li hifdz an nafs), akal (li hifdz al 'akl), keturunan (li hifdz al nash) dan menjaga kekayaan (li hifdz al mal) tanpa mengekang kebebasan individu. ${ }^{36}$

Terdapat beberapa penelitian yang mempunyai kemiripan dengan penelitian yang peneliti tulis, diantara adalah Disertasi yang ditulis oleh Ariawan dengan tujuan untuk menganalisis perjanjian perdagangan bebas dan implikasinya terhadap subjek perjanjian perdagangan bebas termasuk Indonesia, posisi Indonesia dalam perjanjian perdagangan bebas Asean-China Free Trade (ACFTA), efektivitas ACFTA serta kebijakan Indonesia dalam mengoptimalkan ACFTA, peran dan langkah kebijakan Indonesia dalam menghadapi perjanjian perdagangan bebas. Selanjutnya, Yohanes Krisostomos, A.B yang membahas menganai dampak-dampak Perjanjian Perdagangan Lintas Batas terhadap perdagangan lintas batas di Entikong dan membahas kepentingan kelompok yang menghendaki pemerintah Indonesia untuk merevisi Perjanjian Perdagangan Lintas Batas 1970 juga faktor-faktor yang mempengaruhi tidak berubahnya Perjanjian Perdagangan Lintas Batas 1970.

Penelitian yang senada juga dilakukan oleh Antonius Suhardi ${ }^{37}$ yang memperoleh hasil bahwa bahwa ada hubungan satu arah dari FDI dan ekspor terhadap total investasi dan ekspor dari pertumbuhan ekonomi. Penelitian ini

${ }^{36}$ Muhammad dan Rahmad Kurniawan, Visi dan aksi ekonomi Islam: kajian spirit ethico-legal atas prinsip taradin dalam praktik bank Islam modern (Malang: Intimedia, 2014), hlm. 33.

37 Antonius Suhardi, "The Nexus of Investments, International Trade and Economic Growth: The Case of Indonesia" (Universitas Gadjah Mada, 2014), http://etd.repository.ugm.ac.id/index.php?mod=penelitian_detail\&sub=PenelitianDetail\&act=view \&typ=html\&buku_id=75511\&obyek_id=4. 
juga menemukan hubungan dua arah antara pertumbuhan ekonomi dan investasi total. Ada temuan menarik bahwa ekspor memiliki efek negatif pada investasi total dan PDB. Temuan ini menunjukkan bahwa pertumbuhan Indonesia didorong oleh permintaan konsumsi domestik. Berdasarkan kondisi tersebut, Indonesia dapat diklasifikasikan sebagai supply-side ekonomi yang membutuhkan peningkatan pasokan barang dan jasa untuk memenuhi permintaan pasar internal. Tingginya tingkat permintaan domestik di Indonesia harus diimbangi dengan kebijakan sisi penawaran. Intinya, kebijakan sisi penawaran bertujuan untuk mendorong peningkatan kinerja sisi untuk mencapai pertumbuhan ekonomi yang berkelanjutan.

Dari ketiga hasil penelitian tersebut memiliki persamaan dan perbedaan dengan penelitian ini, persamaannya adalah ketiga penelitian tersebut membahas hal-hal yang perhubungan dengan perdagangan dan perjanjian bilateral maupun multilateral yang juga akan peneliti bahas dalam penelitian ini. Adapun yang membedakannya adalah pada peneliitian ini, peneliti mengkaloborasikan hukum poositif yang ada hubungannya dengan perdagangan internasional dengan hukum Islam yang terdapat dalam Alqur'an, dengan demikian penelitian ini akan lebih menarik karena memiliki cita rasa yang berbeda dari yang sebelumnya sehingga layak dikonsumsi oleh para akademisi.

\section{PENUTUP}

Perjanjian perdagangan lintas batas merupakan perjanjian atau kesepakatan yang dibuat oleh pemerintah Indonesia dan Malaysia untuk mengatur perdagangan lintas batas di daerah perbatasan Indonesia dan Malaysia (BTA). Status hukum dalam perjanjian ini adalah mengikat para pihak berdasarkan kesepakatan. Jika ditinjau berdasarkan hukum Islam, maka perjanjian BTA boleh dilaksanakan selama tidak bertentangan dengan syariah Islam sebagaimana tercantum dalam Alqur'an dan hadis. Karena perjanjian BTA perjanjian yang dibuat oleh pemimpin / khalifah dalam sebuah negara yang harus dipatuhi, dengan catatan selama tidak bertentangan dengan ajaran Islam. Hal ini di tegaskan dalam Q.S surah an-Nisa ayat 59. Selain itu, mengingat perjanjian BTA adalah bentuk kesepakatan yang dibuat oleh manusia, maka bukan tidak mungkin perjanjian tersebut tidak bisa lagi menyesuaikan dengan 
FITRAH Jurnal Kajian Ilmu-ilmu Keislaman

Vol. 04 No. 2 Desember 2018

perkembangan zaman dibidang perdagangan, oleh karena itu perlu direvisi/dikaji ulang lagi dengan atas dasar maslahah.

Selain paparan tersebut di atas, seiring perkembangan zaman maka keefektivan perjanjian BTA mulai berkurang, oleh karena itu perlu revisi / pengkajian ulang perjanjian lintas batas Indonsia-Malaysia. Mengingat usia perjanjian lintas batas antara Indonesia sudah cukup lama sedangkan perkembangan perekonomian Negara sudah berkembang. Selain itu, fluktuasi nilai rupiah yang selalu berubah hendaknya menjadi pertimbangan untuk merevisi peraturan tersebut, misal tentang standar maksimal berbelanja, karena nilai RM. 600,- dahulu berbeda dengan sekarang. Oleh karena itu, perlu pertimbangkan lagi sesuai dengan tingkat implasi negara yang membuat kesepakatan. Selain itu, sanksi tegas atas indikasi terhadap pelanggaran perjanjian juga belum dijelaskan.

Pengawasan yang intensif dari para pihak yang membuat perjanjian dengan melibatkan masyarakat perbatasan juga sangat penting, mengingat masyarakat tersebut adalah subjek/pelaku utama yang mengenal betul lingkungnnya, dengan demikian penyeludupan terhadap barang illegal dapat diminimalkan. Kepercayaan pemerintah tersebut dapat menumbuhkan jiwa patriotisme di daerah perbatasan yang mulai menipis oleh arus globalisasi ekonomi maupun politik. Selain itu, meningkatkan taraf pendidikan masyarakat tapal batas (ekonomi, sosial dan budaya) juga perlu perhatian serius oleh pemerintah. Mengingat banyak WNI yang berada diperbatasan yang putus sekolah. Hal tersebut disebabkan oleh rendahnya minat masyarakat terhadap pendidikan dan ketersedian inprastruktur yang belum merata dan guru yang potensial.

Mengingat penelitian ini adalah penelitian normatif dengan analisis studi literatur, pasti ada kekurangan yang terdapat dalam penelitian ini. Oleh karena itu, untuk agar saling melengkapi maka penelitian ini masih memerlukan data dari peneliti lain yang mengkaji hal yang sama dengan sudut pandang yang berbeda yaitu dengan terjun lansung kelapangan untuk melihat realitas perjanjian perdagangan (BTA) yang terjadi diperbatasan saat ini. Selain itu, sangat besar harapan peneliti agar pemerintah membuat tim pengkajian hukum perjanjian lintas batas agar data dan fakta yang didapat dapat dijadikan standar ukur apakah perjanjian BTA layak/tidak untuk direvisi/dikaji lebih lanjut. 


\section{DAFTAR PUSTAKA}

Aa Nurdiaman, dan Betty Susilawati. Pendidikan Kewarganegaraan: Kecakapan Berbangsa dan Bernegara. Jakarta: PT. Pribumi Mekar, 2017.

Abdillah, Aam, dan dkk. Model Penelitian Agama dan Dinamika Sosial: Himpunan Rencana Penelitian. Jakarta: PT Raja grafindo Persada, 2002.

Abdul Kadir, Shofari Sstp. "Implementasi Kebijakan Pengelolaan Pasar Tradisional Di Kabupaten Bantul.” Tesis, Universitas Gadjah Mada, 2011. http://etd.repository.ugm.ac.id/index.php?mod=penelitian_detail\&sub=Pe nelitianDetail\&act=view\&typ=html\&buku_id=50535\&obyek_id=4.

Abubakar, Mustafa. Menata Pulau-Pulau Kecil Perbatasan: Balajar dari Kasus Sempadan, Ligitan dan Sebatik. 2006 ed. Jakarta: Kompas, t.t.

A.M. Fatwa. Potret konstitusi Pasca amandemen UUD 1945. Jakarta: PT Kompas Media Nusantara, 2009.

Ash-Shiddieqy, Muhammad Hasbi. Hukum-Hukum Figh Islam yang Berkembang dalam Kalangan Ahlus Sunnah, cet-5. Jakarta: Bulan Bintang, 1978.

DPR Republik Indonesia. UUD 1945. Jakarta: Visi Media, 2007.

DPR RI. "UU No.39 Thn 1999 - Hak Asasi Manusia (HAM)." Web. Blog. UU No.39 Thn 1999 - Hak Asasi Manusia (HAM), 1999. http://hukum.unsrat.ac.id/uu/uu_39_99.htm.

Eddy, Richard. Aspek legal property: teori, contoh dan aplikasi. Yogyakarta: CV. Andi Offset (ANDI), 2010.

Ekonomi Mikro dalam Prespektif Islam. Yogyakarta: BPFE-Yogyakarta, 2004.

Fachruddin, Fuad. Agama dan Pendidikan Demokrasi: Pengalaman Muhammadiyah dan Nahdlatul Ulama. Jakarta: Pustaka Alvabet dan Yayasan INSEP, 2006.

Ghazaly, M.A, Prof. Dr. H. Abdul Rahman, dan dkk. Figh Muamalat. Jakarta: Kencana, 2012.

Idris, S.E., M.Si, Dr. H. Amiruddin. Pengantar ekonomi sumber daya manusia. Yogyakarta: Deepublish (Grup penerbitan CV budi utama), 2016. 
FITRAH Jurnal Kajian Ilmu-ilmu Keislaman

Vol. 04 No. 2 Desember 2018

Kementerian Perdagangan RI. "Menggenggam Stabilitas Harga Pangan." Publikasi Internal Kementrian Perdagangan Republik Indonesia, INTRA Indonesia TradeInsight 2015, no. V (2014): 1-73.

Kementrian Agama RI. Penistaan Agama dalam Persfektif Pemuka Agama Islam. Jakarta: Puslitbang Kehidupan Keagamaan Badan Litbang dan Diklat Puslitbang Kementrian Agama RI, 2014.

Kementrian agama RI. Tafsir al-qur'an tematik: pembangunan ekonomi umat. Jakarta: PT. sinergi pustaka Indonesia, 2012.

L.M. Gandhi Lapian. Disiblin hukum yang mewujudkan kesetaraan dan keadilan gender. Jakarta: Yayasan Pustaka Obor Indonesia, 2012.

Muhammad, dan Rahmad Kurniawan. Visi dan aksi ekonomi Islam: kajian spirit ethico-legal atas prinsip taradin dalam praktik bank Islam modern. Malang: Intimedia, 2014.

Mu'thi, M.A, Fadlolan Musyaffa'. Islam Agama Mudah: Aplikasi Kaidah "alMasaqqah Tajlib al-Tairis" dalam Konteks Keindonesiaan. Semarang: Syauqi Press, 2007.

Nasution, Darmin. Bank sentral itu harus membumi. Yogyakarta: Galang Pustaka, 2013.

Oesman, Oetojo, Alfian, dan Indonesia Badan Pembinaan Pendidikan Pelaksanaan Pedoman Penghayatan dan Pengamalan Pancasila. Pancasila sebagai ideologi dalam berbagai bidang kehidupan bermasyarakat, berbangsa, dan bernegara. Jakarta: BP-7 Pusat, 1991.

Petebang, Edi. "Kisah Perbatasan:"Merah Putih di Dadaku; Malaysia di Perutku..." (Dimuat di Majalah KR edisi 169, September 2009)." Diakses 19 Oktober 2016. https://www.facebook.com/notes/suara-rakyat/kisahperbatasanmerah-putih-di-dadaku-malaysia-diperutku/10150253228975487/?_rdc=1\&_rdr.

Pusat Pengkajian dan Pengembangan Ekonomi Islam (P3EI) Universitas Islam Indonesia atas kerja sama dengan Bank Indonesia. Ekonomi Islam. Jakarta: PT Raja Grafindo Persada, 2008.

Soeroso, Santoso. Mengarusutamakan pembangunan berwawasan kependudukan di Indonesia. Jakarta: Buku kedokteran EGC, 2005. 
Suhardi, Antonius. "The Nexus of Investments, International Trade and Economic Growth: The Case of Indonesia." Universitas Gadjah Mada, 2014.

http://etd.repository.ugm.ac.id/index.php?mod=penelitian_detail\&sub=Pe nelitianDetail\&act=view\&typ=html\&buku_id=75511\&obyek_id=4.

Sutaryo, Wihana Kirana Jaya, Sri Edi Swasono, Revrisond Baswir, dan Irfan Dwidya Prijambada. Membangun Kedaulatan Bangsa Berdasarkan Nilai-nilai Pancasila: Pemberdayaan Masyarakat Dalam Kawasan Terluar, Terdepan, dan Tertinggal (3T): Kumpulan makalah call for papers kongres Pancasila VII. Yogyakarta: Pusat Studi Pancasila UGM, 2015.

Widoatmodjo, Sawidji. New business model: strategi ampuh menangani bisnis abad ke21 (bagaimana perusahaan lama bertahan dan perusahaan baru masuk). Jakarta: PT alex Media Komputindo (kelompok GRAMEDIA), 2005. 
FITRAH Jurnal Kajian Ilmu-ilmu Keislaman

Vol. 04 No. 2 Desember 2018

\section{PENGARUH BUDAYA NUSANTARA TERHADAP IMPLEMENTASI NILAI-NILAI ISLAM DI INDONESIA}

\section{DOFARI}

Kepala Sekolah SMP Negeri 1 Suruh Kabupaten Semarang Provinsi Jawa Tengah dan Pemerhati Budaya

dofrismpn1@gmail.com 